\title{
Seroprevalence and risk factors associated with bovine herpesvirus 1 and bovine viral diarrhea virus in North-Eastern Mexico
}

\author{
J.C. Segura-Correa ${ }^{1}$, C.C. Zapata-Campos ${ }^{2}, *$ J.O. Jasso-Obregón ${ }^{2}$, J. Martinez-Burnes ${ }^{2}$ and R. López-Zavala ${ }^{2}$ \\ ${ }^{1}$ Campus de Ciencias Biológicas y Agropecuarias, Universidad Autónoma de Yucatán, Km. 5 Carretera Mérida- \\ Xmatkuil, Mérida, Yucatán, C.P. 97315, México \\ ${ }^{2}$ Facultad de Medicina Veterinaria y Zootecnia, Universidad Autónoma de Tamaulipas, Km. 5 A.P. No. 263 \\ C.P. 87000 , Mexico
}

\begin{abstract}
Bovine herpesvirus 1 (BoHV-1) and bovine viral diarrhea virus (BVDV) are well known etiological agents of cattle that produce important economic losses due to reproductive failures and calf mortality, as well as enteric and respiratory disease. Tamaulipas is located northeast of Mexico, an important cattle production and the principal exporter of calf and heifer to the United States. The objectives of this study were to estimate the seroprevalence of BoHV-1 and of BVDV, and to determine the effects of risk factors on these infections. Blood samples of cattle from 57 farms from rural districts of Tamaulipas were collected. The samples were tested for antibodies against BoHV-1 and BVDV using commercial ELISA kits. Data on potential risk factors were obtained using a questionnaire administered to the farmer at the time the blood samples were taken. The seroprevalences for BoHV-1 and BVDV were $64.4 \%$ and $47.8 \%$, respectively. In the logistic regression analysis, the significant risk factors were rural district, herd size and cattle introduced to the farm. This study confirms the high seroprevalence of BoHV-1 and BVDV in unvaccinated cattle in Tamaulipas, Mexico. The results of this study could be used for the development of BoHV-1 and BVDV prevention and control program in North-Eastern, Mexico. Keywords: Bovine, Bovine herpesvirus 1, Bovine viral diarrhea virus, Risk factor, Seroprevalence.
\end{abstract}

\section{Introduction}

Bovine herpesvirus 1 (BoHV-1) and bovine viral diarrhea virus (BVDV) are viruses of cattle that can result in economic losses due to reproductive failures, calf mortality, enteric and respiratory disease. BoHV-1 is a virus of the family Herpesviridae, subfamily Alphaherpesvirinae, the causative agent of infectious bovine rhinotracheitis, a highly contagious, infectious disease (King et al., 2012; Newcomer and Givens, 2016). Typical clinical signs associated with BoHV-1 infection include respiratory disease, but the virus can also be associated with conjunctivitis, vulvovaginitis, abortions, encephalitis and balanoposthitis. The transition from primary manifestations of infection to a latent stage of persistency is often the source of spread after virus reactivation (Viu et al., 2014). BVDV is a Pestivirus from the family Flaviviridae, etiological agent of bovine viral diarrhea/mucosal disease (King et al., 2012). Clinical signs include pyrexia, diarrhea and reduced production; it is a highly morbid disease but cause low mortality of infected animals (Grooms, 2004; Nardelli et al., 2008). Both BVDV type 1 and 2 are present in Mexico. Infection of pregnant cows can result in transplacental fetal infection. Fetuses may be aborted, mummified, stillborn or born with severe anomalies. In many cases, immunotolerant (persistently infected) calves are born (Van Oirschot et al., 1999). Also, BVDV can have immunosuppressive effects, which predispose animals to infection by other microorganisms (Reggiardo and Kaeberle, 1981). The use of vaccines may reduce the economic losses caused by clinical disease, but does not seems to reduce the prevalence of either BVDV or BoHV-1 infections (Xue et al., 2011). It is difficult to accurately estimate the real economic impact due to infected animals that often have no clinical signs of these infections. BoHV-1 and BVDV are widespread in Mexico as indicated by previous studies (Solis-Calderon et al., 2003, 2005; Magaña-Urbina et al., 2005; Segura-Correa et al., 2010). However, state differences may exist within a country and between regions. Risk factors effects may also varied from region or farm to farm because microclimatic changes, management differences, stock densities, along with other factors (Almeida et al., 2013). BVDV is spread between herds mainly by cattle movement, live vaccines use, semen and embryos, visitors, including veterinaries and artificial insemination technicians (Lindberg and Alenius, 1999). Some European studies report several risk factors associated to infection with BoHV-1 such as animal age, vaccination status, herd size, production system (dairy or beef), season and introduction of animals to the farm (Boelaert et al., 2005; González-Garcia et al., 2009). Several reports associated risk factor to BVDV infection such as density of cattle farms, altitude, more than six calves aged $\leq 12$ months, animal purchasing 
and presence of veterinary assistance (Saa et al., 2012; Fernandes et al., 2016). Therefore, information on the epidemiology of BoHV-1 and BVDV is important to establish if tailored prevention and control programs are required for specific regions. The purpose of this study was to estimate the seroprevalence of BVDV and BoHV-1 in cattle and evaluate risk factors in northeast of Mexico.

\section{Area of study}

\section{Materials and Methods}

The state of Tamaulipas is located at northeast Mexico between $22^{\circ} 13^{\prime}$ and $27^{\circ} 40^{\prime} \mathrm{N}$ and $97^{\circ} 09^{\prime}$ and $99^{\circ}$ $58^{\prime} \mathrm{W}$. The climate in the State varies from humid to semi-dry. Cattle production is an important activity in Tamaulipas which has a population of approximately $1,366,489$ cattle and is the principal exporter of calf and heifer to the United States (SIAP, 2015). According to SAGARPA (Mexican Agricultural Department), Tamaulipas is divided into nine rural districts: Jaumave, Matamoros, Mante, Victoria, Gonzalez, Abasolo, San Fernando, Laredo and Díaz Ordaz.

\section{Animals and sample collection}

To estimate seroprevalence, the total cattle population of Tamaulipas $(985,896$ heads) was taken into account (INEGI, 2007). The number of animals sampled ( $n=385$ heads of more than 6 months) in the study was calculated considering an expected prevalence of $50 \%$, a confidence level of $95 \%$ and a precision of $5 \%$ (Segura and Honhold, 2000). Farms and animals within farms were randomly selected. The smallest farm sampled had at least 50 animals. One to 17 heads were sampled per farm. Blood samples were collected from cattle of reproductive age (both sexes). All included animals were not vaccinated against BoHV-1 or BVDV. To identify possible risk factors associated to those diseases, a questionnaire was provided to farm owners, to collect information on putative herd and animal level risk factors. Most of the animals sampled belonged to the Zebu type crosses. There were no clinical signs in the animals recorded at sampling, conducted between May 2010 and December 2011.

Blood samples $(10 \mathrm{~mL})$ were collected from the coccygeal vein of each animal, using disposable needles $(21 \mathrm{~mm} 1.5 \mathrm{~mm})$ and vacutainer tubes. The samples were identified and transported on ice to the Diagnostic Laboratory of the Veterinary Medicine Faculty of University Autonomous from Tamaulipas. The blood samples were centrifuged at 1,500 $\mathrm{g}$ at $4^{\circ} \mathrm{C}$ for $10 \mathrm{~min}$ and the serum was transferred into disposable microcentrifuge tubes (Eppendorf $\AA$ ) and stored at $-20^{\circ} \mathrm{C}$ until testing.

\section{Laboratory analysis}

Blood samples were tested for antibodies against BoHV-1 and BVDV using HerdCheck IBRgB Ab and HerdCheck BVDV p80 Ab ELISA kits (IDEXX laboratories Inc., Westbrook; Maine 04092 USA).
The tests were performed according to manufacturer's instructions. A blocking ELISA assay was used for the detection of IgG antibodies against BVDV in serum o plasm, and an indirect ELISA assay for the detection de antibodies anti BoHV-1 using monoclonal antibodies. The results were read in a microplate photometer, where the optical density (OD) was measured at $450 \mathrm{~nm}$. The cut off OD was calculated as A = OD (corrected negative control) 2.0. All samples with an OD greater or equal than 0.25 were considered positives. The sensitivity and specificity of these tests were $100 \%$ and $99.5 \%$ respectively.

\section{Potential risk factors}

Data on potential risk factors were obtained using a questionnaire provided to the farmer at the time the blood samples were collected. The factors evaluated were rural district; herd size (50-200, 201-500, >500 animals), production system (dairy, beef), cattle introduced to the farm (no, yes), replacement origin (own farm; purchased), water origin (Tube water, reservoir, stream, well), age of cattle (6-36, 37-69 and 70-216 months) and sex (female, male).

\section{Data analysis}

Descriptive statistics were used to calculate the frequency of seropositive animals for antibodies against BoHV-1 and BVDV. A primary screening test to identify risk factors significantly related to BoHV-1 and BVDV seropositivity was performed using chi-square tests. Only those factors associated $(\mathrm{P}<0.10)$ with the response variable were offered to the logistic binomial regression models. All statistical analyses were carried out using the SAS package (SAS, 2008).

\section{Results}

Overall seroprevalence values for BoHV-1 and BVDV were $64.4 \%$ and $47.8 \%$, respectively. Among 385 cattle sampled, 142 animals were detected to have antibodies against both viruses and 93 were free of antibodies to both viruses. Seroprevalence and chi-square test results for BoHV-1 and BVDV are shown in Tables 1 and 2, respectively. Preliminary chi-square tests showed associations $(\mathrm{P}<0.10)$ between the presence of antibodies to BoHV-1 and rural district, herd size, cattle introduced to the farm, replacement origin and water origin (Table 1); whereas the presence of antibodies against BVDV were associated with rural district, production system, herd size, and cattle introduced to the farm (Table 2).

In the logistic regression analyses, the significant risk factors were rural district, herd size and cattle introduced to the farm for BVDV (Table 3); and rural district and herd size for BoHV-1 (Table 4). The lowest seroprevalences for BoHV-1 and BVDV were observed in the rural district of Matamoros and the highest in Laredo and Abasolo, respectively (Tables 1 and 2). Seroprevalences of BoHV-1 and BVDV were significantly higher in large and middle herds, respectively $(\mathrm{P}<0.05)$. Farms 
that introduced animals to their herds showed higher odds of antibodies against BVDV.

Table 1. Seroprevalence by risk factor for bovine herpesvirus 1 in Tamaulipas, Mexico $(\mathrm{n}=385)$.

\begin{tabular}{|c|c|c|c|c|}
\hline \multirow[t]{2}{*}{ Risk factor } & \multirow{2}{*}{$\begin{array}{c}\text { Number } \\
\text { of } \\
\text { animals }\end{array}$} & \multicolumn{2}{|c|}{ Positive } & \multirow[t]{2}{*}{$p$ value } \\
\hline & & Number & $\%$ & \\
\hline Rural district & & & & $<0.0001$ \\
\hline Matamoros & 10 & 2 & 20.00 & \\
\hline Mante & 26 & 13 & 50.00 & \\
\hline Victoria & 67 & 39 & 58.21 & \\
\hline Gonzalez & 106 & 58 & 54.72 & \\
\hline Abasolo & 72 & 46 & 63.89 & \\
\hline San Fernando & 48 & 37 & 77.08 & \\
\hline Laredo & 56 & 55 & 98.21 & \\
\hline Production system & & & & 0.6947 \\
\hline Beef & 330 & 213 & 64.55 & \\
\hline Dairy & 55 & 37 & 67.27 & \\
\hline $\begin{array}{l}\text { Introduction of } \\
\text { animals to the herd }\end{array}$ & & & & $<0.0001$ \\
\hline Yes & 113 & 90 & 80.53 & \\
\hline No & 272 & 158 & 58.19 & \\
\hline Sex & & & & 0.9085 \\
\hline Female & 346 & 225 & 65.03 & \\
\hline Male & 39 & 25 & 64.10 & \\
\hline Age group (months) & & & & 0.3896 \\
\hline $6-36$ & 134 & 82 & 61.19 & \\
\hline $37-69$ & 139 & 96 & 69.06 & \\
\hline $70-216$ & 112 & 72 & 64.29 & \\
\hline Management & & & & 0.2910 \\
\hline extensive & 324 & 214 & 66.05 & \\
\hline Intensive & 61 & 36 & 59.02 & \\
\hline Herd size (head) & & & & 0.0170 \\
\hline $50-200$ & 176 & 101 & 57.39 & \\
\hline $201-500$ & 92 & 65 & 70.65 & \\
\hline$>500$ & 117 & 84 & 71.79 & \\
\hline Replacement origin & & & & $<0.0001$ \\
\hline Outside & 100 & 46 & 46.00 & \\
\hline Own herd & 285 & 204 & 71.58 & \\
\hline Water origin & & & & 0.0064 \\
\hline Tube water & 126 & 74 & 58.73 & \\
\hline Reservoir & 165 & 101 & 61.21 & \\
\hline Stream-river & 37 & 29 & 78.38 & \\
\hline Well & 57 & 46 & 80.70 & \\
\hline
\end{tabular}

Table 2. Seroprevalence by risk factor for bovine viral diarrhea virus in Tamaulipas, Mexico ( $\mathrm{n}=385)$.

\begin{tabular}{|c|c|c|c|c|}
\hline \multirow[t]{2}{*}{ Risk factor } & \multirow{2}{*}{$\begin{array}{c}\text { Number } \\
\text { of } \\
\text { animals }\end{array}$} & \multicolumn{2}{|c|}{ Positive } & \multirow[t]{2}{*}{$p$ value } \\
\hline & & Number & $\%$ & \\
\hline Rural district & & & & 0.0007 \\
\hline Matamoros & 10 & 1 & 10.00 & \\
\hline Mante & 26 & 11 & 42.31 & \\
\hline Victoria & 67 & 34 & 50.75 & \\
\hline Gonzalez & 106 & 44 & 41.51 & \\
\hline Abasolo & 72 & 45 & 62.50 & \\
\hline San Fernando & 48 & 15 & 31.25 & \\
\hline Laredo & 56 & 34 & 60.71 & \\
\hline $\begin{array}{l}\text { Production } \\
\text { system }\end{array}$ & & & & 0.0503 \\
\hline Beef & 330 & 151 & 45.76 & \\
\hline Dairy & 55 & 33 & 60.00 & \\
\hline $\begin{array}{l}\text { Introduction of } \\
\text { animals to the } \\
\text { herd }\end{array}$ & & & & 0.0685 \\
\hline Yes & 113 & 63 & 55.75 & \\
\hline No & 272 & 122 & 44.85 & \\
\hline Sex & & & & 0.6453 \\
\hline Female & 346 & 164 & 47.40 & \\
\hline Male & 39 & 20 & 51.28 & \\
\hline $\begin{array}{l}\text { Age } \\
\text { group (months) }\end{array}$ & & & & 0.7295 \\
\hline $6-36$ & 134 & 66 & 49.25 & \\
\hline $37-69$ & 139 & 68 & 48.92 & \\
\hline $70-216$ & 112 & 50 & 44.64 & \\
\hline Management & & & & 0.7473 \\
\hline extensive & 324 & 156 & 48.15 & \\
\hline Intensive & 61 & 28 & 45.90 & \\
\hline Herd size (heads) & & & & $<0.0001$ \\
\hline $50-200$ & 176 & 67 & 38.07 & \\
\hline $201-500$ & 92 & 66 & 71.74 & \\
\hline$>500$ & 117 & 51 & 43.59 & \\
\hline $\begin{array}{l}\text { Replacement } \\
\text { origin }\end{array}$ & & & & 0.3776 \\
\hline Outside & 100 & 44 & 44.00 & \\
\hline Own herd & 285 & 140 & 49.12 & \\
\hline Water origin & & & & 0.1879 \\
\hline Tube water & 126 & 58 & 46.03 & \\
\hline Reservoir & 165 & 85 & 51.52 & \\
\hline Stream-river & 37 & 12 & 32.43 & \\
\hline Well & 57 & 29 & 50.88 & \\
\hline
\end{tabular}


Table 3. Results of the logistic regression for bovine viral diarrhea virus seroconversion.

\begin{tabular}{lcccc}
\hline Risk factor & $b$ & $E E$ & $O R$ & $95 \% C I_{O R}$ \\
\hline Rural district & & & & \\
Matamoros & -1.640 & 1.017 & 0.05 & $0.01,0.43$ \\
Mante & 2.324 & 0.602 & 2.54 & $0.48,13.4$ \\
Victoria & 0.670 & 0.421 & 0.49 & $0.10,2.27$ \\
Gonzalez & -1.586 & 0.462 & 0.05 & $0.01,0.26$ \\
Abasolo & 0.465 & 0.416 & 0.40 & $0.08,1.94$ \\
San Fernando & -1.626 & 0.433 & 0.05 & $0.01,0.19$ \\
Laredo & 0 & - & 1 & - \\
Introduce animals & & & & \\
Yes & 0.913 & 0.2700 & 6.21 & $2.15,17.9$ \\
No & 0 & - & 1 & - \\
Herd size (heads) & & & & \\
50-200 & -1.534 & 0.2675 & 0.20 & $0.09,0.46$ \\
201-500 & 1.474 & 0.2541 & 4.11 & $1.90,8.89$ \\
$>500$ & 0 & - & 1 & - \\
\hline
\end{tabular}

b: regression coefficient; EE: standard error of b; OR: odds ratios; $95 \% \mathrm{CI}_{\mathrm{OR}}: 95 \%$ confidence interval of $\mathrm{OR}$.

Table 4. Results of the logistic regression for bovine herpesvirus 1 seroconversion data.

\begin{tabular}{lcccc}
\hline Risk factor & $b$ & $E E$ & $O R$ & $95 \% C_{\text {oR }}$ \\
\hline Rural district & & & & \\
Matamoros & -1.1151 & 0.9511 & 0.017 & $0.001,0.254$ \\
Mante & 0.4730 & 0.5554 & 0.084 & $0.007,0.990$ \\
Victoria & -0.4559 & 0.4033 & 0.033 & $0.003,0.358$ \\
Gonzalez & -1.5031 & 0.4405 & 0.012 & $0.001,0.130$ \\
Abasolo & 0.2386 & 0.4060 & 0.041 & $0.004,0.466$ \\
San Fernando & -0.1133 & 0.4136 & 0.047 & $0.005,0.462$ \\
Laredo & 0 & - & 1 & - \\
Herd size (heads) & & & & \\
50-200 & -0.7886 & 0.2172 & 0.415 & $0.199,0.869$ \\
201-500 & 0.6989 & 0.2018 & 1.839 & $0.926,3.652$ \\
$>500$ & 0 & - & 1 & - \\
\hline
\end{tabular}

\section{Discussion}

BoHV-1 and BVDV are involved in the respiratory disease complex. BVDV can induce a variety of clinical manifestations which may vary from clinically in apparent infection to acute or chronic severe disease (Baker, 1995). However, the most important economical consequence of BVDV infection is reproductive losses (De Vries, 2006). Clinical signs of BoHV-1 include symptoms of inflammatory processes in both respiratory and genital organs, and abortion (OIE, 2010).
The seroprevalence to BoHV-1 here found (64.4\%) is higher than that of cattle in Yucatan, (54.4\%) (SolisCalderon et al., 2003) and Michoacán, Mexico (22\%) (Magaña-Urbina et al., 2005). However, the prevalences in this study are lower than those reported by CórdovaIzquierdo et al. (2007) in humid tropics of Mexico $(90 \%)$. Seroprevalences of BoHV-1 in the literature range from 7.5 up to $70.89 \%$ (Solis-Calderon et al., 2003; Eiras et al., 2009; Gupta et al., 2010; Cedeño et al., 2011; Raizman et al., 2011; Yousef et al., 2013; Saravanajayam et al., 2015). The seroprevalence found in this study for BoHV-1, indicates that it is a widely distributed infection in the region.

The seroprevalence to BVDV determined in this study was $47.8 \%$ which is within the range 6.3 to $75 \%$ of seroprevalences reported in Mexico and other countries in Latin-America (Orjuela et al., 1991; Obando et al., 1999; Moles et al., 2002; Solis-Calderon et al., 2005; Ramirez-Vazquez et al., 2016). Differences in antibody prevalence between regions and countries could in part be explained by factors such as production system, herd size, disease-control measures, type of breeding, and age of the animal, this is important because indicates the permanence in the environment of both diseases (Orjuela et al., 1991; Mainar-Jaime et al., 2001). The BVDV infection could be controlled in the region by not allowing the introduction of persistently infected animals from infected herds. Lindberg and Alenius (1999) reported BVDV infection eradication without any other intervention than controlled introduction of new animals.

The high seroprevalences found in this study, indicates that BoHV-1 and BVDV are common in all rural districts of Tamaulipas. High seroprevalence for those infections have been reported in other parts of Mexico (Solis-Calderon et al., 2003, 2005; Magaña-Urbina et al., 2005). Animals having antibodies to BoHV-1 and BVDV may be infected by respiratory or via reproductive tract. Therefore, control measures should be installed to prevent contagion between animals of the same region and between other regions.

\section{Risk factors}

\section{Rural district}

There were significant differences between seroprevalence of a given virus in different rural districts. This heterogeneity may be related to the density of farms in each rural district; differences in prevalence between districts and by factors such as herd size, disease control measures, type of breeding and age of the animal (McDermott et al., 1997).

\section{Herd size}

Detection of significant differences in the seroprevalence among herd sizes indicates that this is an important risk factor for BoHV-1 and BVDV infections. Orjuela et al. (1991) reported in Colombia a high seroprevalence for BVDV in middle-sized farms $(9.1 \%)$ when compared 
to small $(6.2 \%)$ and large farms $(3.4 \%)$; which agree with the results of this study (Tables 3 and 4), where the odds of infection was 4.11 times the level of infection in large herds. McDermott et al. (1997) and Van Wuyckhuise et al. (1998) reported; however, that large herds or herds with high stock density are associated with high odds for IBR.

Introduction of animals or cattle origin

The lack of differences in the seroprevalence of BoHV-1 between introduced or not introduced animals to the herd agrees with the results of Solis-Calderon et al. (2003). However, the introduction or not of animals was an important risk factor for BVDV $(\mathrm{OR}=6.21)$, which suggest the purchasing of persistently infected animals. Solis- Calderon et al. (2005) reported that purchase of cows (introduction of animals to the herd) in small herds increased the prevalence and risk of BVDV infection as compared to middle and large herd sizes. Mainar-Jaime et al. (2001) in dairy cattle in Spain found that the seroprevalence of purchased cows was much higher than for cows whose origin was the farm. However, seropositive animals are not the main risk of infection of BVDV, but the presence of persistently infected (seronegative) animals in the herd.

Age group of animals

Age group is a frequent reported risk factor for BoHV-1 seropositivity. De Quevedo et al. (1978), Orjuela et al. (1991), McDermott et al. (1997), Hage et al. (1998) and Solis-Calderon et al. (2003) reported higher seroprevalence in old animals. However, in this study, age was not a significant risk factor. The similar seroprevalence of BVDV observed among the three agegroups suggest the dissemination of persistently infected animals in the herds studied. The distribution of virus and risk factors identification are important in order to establish prevention and control programs against economically important diseases such as BVD and IBR. In conclusion, this study confirms the high seroprevalence of BoHV-1 and BVDV in nonvaccinated cattle in Tamaulipas, Mexico. The fact that animals were not vaccinated and that all age-groups had high seroprevalence indicates that the BoHV-1 and BVDV are naturally circulating in this population. So is urgently needed to establish measures for the epidemiological control and prevention of these diseases to decrease their incidence.

\section{Conflict of interest}

The authors declares that there is no conflict of interest.

\section{Acknowledgments}

The authors would like to acknowledge the FOMIXTamaulipas/CONACYT for financial support of this project (TAMPS-2008-C17-107297).

\section{References}

Almeida, L.L., Miranda, I.C.S., Hein, E.E., Neto, S.W., Costa, E.F., Marks, F.S., Rodenbush, C.R.,
Canal, C.W. and Corbellini, L.G. 2013. Herd-level risk factors for bovine viral diarrhea virus infection in dairy herds from southern Brazil. Res. Vet. Sci. 95, 901-902.

Baker, C.J. 1995. The clinical manifestations of bovine viral diarrhea infection. Vet. Clin. North Am. Food Anim. Pract. 11, 425-445.

Boelaert, F., Speybroeck, N., De Kruif, A., Aerts, M., Burzykowski, T., Molenberghs, G. and Berkvens, D.L. 2005. Risk factors for bovine herpesvirus-1 seropositivity. Prev. Vet. Med. 69, 285-295.

Cedeño, Q.J., Benavides, B.B., Cardenas, G. and Herrera, C. 2011. Seroprevalence and risk factors associated to BHV-1 and DVBV in dairy herds in Pasto, Colombia in 2011. Rev. Lasallista Invest. 8, 61-68.

Córdova-Izquierdo, A., Córdova-Jiménez, C., SaltijeralOaxaca, J., Ruiz-Lang, C., Cortes-Suarez, S. and Guerra-Liera, J. 2007. Seroprevalencia de enfermedades causantes de aborto bovino en el trópico húmedo Mexicano. Rev. Vet. 18, 139-142.

De Quevedo, J.M., Aguilar, S.A., Correa, G.P. and Berruecos, J.M. 1978. Algunos aspectos epizotiológicos de la rinotraqueitis infecciosa bovina. Tec. Pecu. Mex. 34, 61-68.

De Vries, A. 2006. Economic value of pregnancy in dairy cattle. J. Dairy Sci. 89, 3876-3885.

Eiras, C., Dieguez, F.J., Sanjuán, M.L., Yus, E. and Arnaiz, I. 2009. Prevalence of serum antibodies to bovine herpesvirus-1 in cattle in Galicia (NW Spain). Spanish J. Agric. Res. 7, 801-806.

Fernandes, L.G., Nogueira, A.H., De Stefano, E., Pituco, E.M., Ribeiro, C.P., Alves, C.J., Oliveira, T.S., Clementino, I.J. and de Azevedo, S.S. 2016. Herd-level prevalence and risk factors for bovine viral diarrea virus infection in cattle in the state of Paraiba, Northeastern. Trop. Anim. Health Prod. 48, 157-165.

González-Garcia, M.A., Arenas-Casas, A., Carbonero-Martínez, A., Borge-Rodríguez, C., García-Bocanegra, I., Maldonado, J.L., Gómez, J.M. and Perea-Remujo, J.A. 2009. Seroprevalence and risk factors associated with bovine herpesvirus type 1 (BHV-1) infection in non-vaccinated cattle herds in Andalusia (South of Spain). Spanish J. Agric. Res. 3, 550-554.

Grooms, D.L. 2004. Reproductive consequences of infection with bovine viral diarrhea virus. Vet. Clin. North Am. Food Anim. Pract. 20, 5-19.

Gupta, A.K., Chahar, A., Tanwar, R.K. and Fakhruddin K. 2010. Seroprevalence of infectious bovine rhinotracheitis in cattle. Vet. Practitioner 11, 169-170.

Hage, J.J., Schukken, Y.H., Digkstra, T.H., Barkema, H.W., VanValkengoed, P.H.R. and Wentink, G.H. 1998. Milk production and 
reproduction during a subclinical bovine herpesvirus infection on a dairy farm. Prev. Vet. Med. 34, 97-106.

Instituto Nacional de Estadística Geográfica e Informática (INEGI). 2007. Anuario estadístico del Estado de Tamaulipas. Síntesis geográfica de Tamaulipas. XI Censo General de Población y Vivienda. http://www.inegi.org.mx/est/contenidos/ proyectos/Agro/ca2007/Resultados_Agricola/ default.aspx. Accessed: 15 Feb. 2016.

King, A.M.Q., Adams, M.J., Carstens, E.B. and Lefkowitz, E.J. 2012. Virus Taxonomy: Classification and Nomenclature of Viruses: Ninth Report of the International Committee on Taxonomy of Viruses. San Diego, CA: Elsevier/ Academic Press, pp: 1010.

Lindberg, A.L.E. and Alenius, S. 1999. Principles for eradication of bovine viral diarrhoea virus (BVDV) infection in cattle populations. Vet. Microbiol. 64, 197-222.

Magaña-Urbina, A., Solorio Rivera, J.L. and Segura-Correa, J.C. 2005. Rinotraqueitis infecciosa bovina en hatos lecheros de la región Cotzio-Téjaro, Michoacán, México. Tec. Pecu. Mex. 43, 27-37.

Mainar-Jaime, R.C., Berzal-Herranz, B., Arias, P. and Rojo-Vázquez, F.A. 2001. Epidemiological pattern and risk factors associated with bovine viraldiarrhoea (BVDV) infection in a non-vaccinated dairy-cattle population from the Asturias region of Spain. Prev. Vet. Med. 52, 63-73.

McDermott, J.J., Kadohira, M., O'Callaghan, C.J. and Shoukri, M.M. 1997. A comparison of different models for assessing variation in the seroprevalence of infectious bovine rhinotracheitis by farm, area and district in Kenya. Prev. Vet. Med. 32, 219-234.

Moles, L.P., Gavaldón, D., Torres, J.I., Cisneros, M.A., Aguirre, J. and Rojas, N. 2002. Seroprevalencia simultanea de Leptospirosis y tres enfermedades de importancia reproductiva en bovinos del altiplano central de la República Mexicana. Revista Salud Animal 24(2), 106-110.

Nardelli, S., Farina, G., Luchini, R., Valorz, C., Moresco, A., Dal Zotto, R. and Costanzi, C. 2008. Dynamic of infection and immunity in a dairy cattle population undergoing and eradication programme for infectious bovine rhinotracheitis (IBR). Prev. Vet. Med. 85, 68-80.

Newcomer, B.W. and Givens, D. 2016. Diagnosis and control of viral diseases of reproductive importance: Infectious Bovine Rhinotracheitis and Bovine Viral Diarrhea. Vet. Clin. North Am. Food Anim. Pract. 34, 425-441.

Obando, R.C., Hidalgo, M., Merza, M., Montoya, A., Klingeborn, B. and Moreno-López, J. 1999. Seroprevalence to bovine virus diarrhoea virus and other viruses of the bovine respiratory complex in Venezuela (Apure State). Prev. Vet. Med. 41, 271-278.

OIE Handdistatus II. 2010. Accessed 15 may 2016. http://www.oie.int/hs2/report.asp.

Orjuela, J., Navarrete, M., Betancourt, A., Roqueme, L., Cortez, E. and Morrison, R.B. 1991. Salud y productividad en bovinos de la costa norte de Colombia. World Anim. Rev. 69, 7-14.

Raizman, E.A., Pogranichniy, R., Negron, M., Schnur, M. and Tobar-Lopez, D.E. 2011. Seroprevalence of infectious bovine rinotracheitis and bovine viral diarrhea virus type 1 and type 2 in non-vaccinated cattle herds in The Pacific Region of Central Costa Rica. Trop. Anim. Health Prod. 43, 773-778.

Ramirez-Vazquez, N.F, Fernández-Silva, J.A, Villar-Argaiz, D., Landaño-Pino, J., Chaparro-Gutierrez, J. and Olivera-Angel, M.E. 2016. Seroprevalencia de la diarrea viral bovina, herpesvirus bovino y virus sincitial respiratorio en Argentina. Rev. CES. Med. Vet. Zoo. 11, 1.

Reggiardo, C. and Kaeberle, M.L. 1981. Detection of bacteremia in cattle inoculated with bovine viral diarrhea virus isolated from cases of mucosal disease. Vet. Microbiol. 13, 361-369.

Saa, L.R., Perea, A., Garcia-Bocanegra, I., Arenas, A.J., Jara, D.V., Ramos, R. and Carbonero, A. 2012. Seroprevalence and risk factors associated with bovine viral diarrhea virus (BVDV) infection in non-vaccinated dairy and dual purpose cattle herd in Ecuador. Trop. Anim. Health Prod. 44, 645-649.

Saravanajayam, M., Kumanam, K. and Balasubramaniam, A. 2015. Seroepidemiology of Infectious Bovine Rhinotracheitis in unvaccinated cattle. Vet. World 8(12), 1416-1419.

SAS, 2008. SAS/STAT User's Guide, Version 9.2. SAS Institute Inc., Cary, NC. USA.

Segura-Correa, J.C., Solorio Rivera, J.L. and Sánchez-Gil, L. 2010. Seroconversion to bovine viral diarrhoea virus and infectious bovine rhinotracheitis in dairy herds of Michoacan, Mexico. Trop. Anim. Health Prod. 42(2), 233-238.

Segura, J.C. and Honhold, N. 2000. Métodos de Muestreo para la Producción y Salud Animal. Universidad Autónoma de Yucatán. Mérida, Yucatán, México, pp: 139.

Servicio de Información Agroalimentaria y pesquera (SIAP).Ganadería.2015.Accessed:1 Sep.2015 http:// www.siap.gob.mx/exportacion-de-ganado-bovino/.

Solis-Calderon, J.J., Segura-Correa, V.M. and Segura-Correa, J.C. 2005. Bovine viral diarrhoea virus in beef cattle herds of Yucatan, Mexico: Seroprevalence and risk factors. Prev. Vet. Med. 72, 253-262.

Solis-Calderon, J.J., Segura-Correa, V.M., Segura-Correa, J.C. and Alvarado-Islas, A. 2003. Seroprevalence of and risk factors for infectious 
bovine rhinotracheitis in beef cattle herds of Yucatan, Mexico. Prev. Vet. Med. 57, 199-208.

Van Oirschot, J.T., Bruschke, C.J.M. and van Rijn, P.A. 1999. Vaccination of cattle against bovine viral diarrhoea. Vet. Microbiol. 64, 169-183.

Van Wuyckhuise, L., Bosch, I., Franken, P., Frankena, K. and Elbers, A.R.W. 1998. Epidemiological characteristics of bovine herpesvirus-1 infections determined by bulk milk testing of all Dutch daily herds. Vet. Rec. 142, 181-184.

Viu, M.A., Dias, L.R.O., Lopes, D.T., Viu, A.F.M. and Ferraz, H.T. 2014. Infectious bovine rhinotracheitis:
Review. Pub.Vet. 8(4).

Xue, W., Mattick, D. and Smith, L. 2011. Protection from persistent infection with a bovine viral diarrhea virus (BVDV) type $1 \mathrm{~b}$ strain by a modified-live vaccine containing BVDV types $1 \mathrm{a}$ and 2 , infectious bovine rhinotracheitis virus, parainfluenza 3 virus and bovine respiratory syncytial virus. Vaccine 29, 4657-4662.

Yousef, M.R., Mahmoud, M.A., Ali, S.M. and Al-Blowi, M.H. 2013. Seroprevalence of some bovine viral respiratory diseases among non vaccinated in Saudi Arabia. Vet. World 6(1), 1-4. 